\title{
The Unfolded Protein Response and Gastrointestinal Disease
}

\author{
Arthur Kaser ${ }^{1}$, Timon Erik Adolph ${ }^{1}$, and Richard S Blumberg ${ }^{2}$ \\ ${ }^{1}$ Div of Gastroenterology and Hepatology, Dept of Medicine, University of Cambridge, \\ Addenbrooke's Hospital, Cambridge, UK \\ ${ }^{2}$ Div of Gastroenterology, Hepatology and Endoscopy, Dept of Medicine, Brigham and Women's \\ Hospital, Harvard Medical School, Boston, MA
}

\begin{abstract}
As the inner lining of the gastrointestinal tract, the intestinal epithelium serves an essential role in innate immune function at the interface between the host and microbiota. Given the unique environmental challenges and thus physiologic secretory functions of this surface, it is exquisitely sensitive to perturbations that affect its capacity to resolve endoplasmic reticulum (ER) stress. Genetic deletion of factors involved in the unfolded protein response (UPR), which functions in the resolution of ER stress that arises from misfolded proteins, result in spontaneous intestinal inflammation closely mimicking human inflammatory bowel disease (IBD). This is demonstrated by observations wherein deletion of genes such as $X b p 1$ and $A g r 2$ profoundly affects the intestinal epithelium and results in spontaneous intestinal inflammation. Moreover, both genes, along with others (e.g. ORDML3) represent genetic risk factors for human IBD, both Crohn's disease and ulcerative colitis. Here we review the current mechanistic understanding for how unresolved ER stress can lead to intestinal inflammation, and highlight the findings that implicate ER stress as a genetically affected biological pathway in IBD. We further discuss environmental and microbial factors that might impact on the epithelium's capacity to resolve ER stress, and which may constitute exogenous factors that may precipitate disease in genetically susceptible individuals.
\end{abstract}

\section{Introduction}

The intestinal epithelium is the inner monolayer lining of the gastrointestinal tract which, from a teleological point of view, is the functional quintessence of the intestine as an organ. Intestinal epithelial cells (IECs) absorb nutrients and fulfill the remarkable task of separating the abundance of the commensal microbiota from the host environment [1]. Several types of IECs differentiate from a constantly replicating intestinal stem cell that has been well characterized in the small and the large intestine, and which forms the basis for the continuous replenishment of the intestinal epithelial surface every $48-72 \mathrm{~h}$ in rodents and $72-96 \mathrm{~h}$ in humans $[2,3]$. The types of differentiated IECs are absorptive epithelial cells, which express a multitude of molecular transporters on their microvillous surface; enteroendocrine cells, which secrete hormones and other mediators that relay metabolic information to peripheral organs; Paneth cells at the base of small intestinal crypts (and analogous $\mathrm{CD} 24^{+}$cells in colonic crypts [4,5]), which provide the niche for intestinal stem cells, secrete abundant amounts of antimicrobial peptides that contribute to the host resistance to infection and contribute to the selective pressure imposed onto the intestinal

Correspondence: Richard S Blumberg, Div of Gastroenterology, Hepatology and Endoscopy, Dept of Medicine, Brigham and Women's Hospital, Thorn 1405, 75 Francis St, Boston, MA 02115, USA, rblumberg@ partners.org. Arthur Kaser, Div of Gastroenterology and Hepatology, Dept of Medicine, University of Cambridge, Addenbrooke's Hospital, Level 5, Box 157, Cambridge CB2 0QQ, UK, ak729@cam.ac.uk.

The author's declare that they have no conflict of interests. 
microbial flora; and goblet cells, which secrete massive quantities of mucins, which constitute the highly organized and complex mucin layer which represents an integral key part of the intestinal barrier $[2,6]$. In addition to these characteristic functions of the differentiated IEC types are their individual roles as central organizers of the mucosal immune system via secretion of key cytokines and chemokines [7], and in fact, the intestinal epithelium could be considered the most ancient part of the innate immune system [8]. In their entirety, covering $300 \mathrm{~m}^{2}$ of intestinal surface area, IECs represent a massive, highly secretory organ that operates in a physiological environment quite adverse to the energydependent process of protein folding [9]. This includes an almost anaerobic milieu, high cellular turn-over, and exposure to microbial metabolites and toxins that may impact on protein folding. It is therefore not surprising that unimpaired handling of protein misfolding is critical for the physiological functions of IECs, and correspondingly, highly secretory Paneth and goblet cells appear most affected by impairment in UPR function [9].

ER stress elicits the UPR via three main ER transmembrane sensors which cooperate with the chaperone grp78 to sense misfolded proteins [10-12]: IRE1 (inositol-requiring enzyme 1), PERK (Protein Kinase Related-like ER kinase), and ATF6 (Activating transcription factor $6 ; \alpha$ and $\beta$ isoforms), amongst which IRE1 represents the evolutionarily most conserved branch of the UPR. The epithelium of the digestive and respiratory tracts are unique in that they express an additional isoform along with ubiquitously expressed IRE1a, namely IRE1 $\beta$ [13], which can be interpreted as an evolutionary hint toward the importance of ER stress sensing at mucosal barriers. Upon sensing of misfolded proteins, IRE1 is autophosphorylated via its kinase domain, forms dimers and activates its endoribonuclease domain which results in unconventional splicing of $X B P 1$ (X-box binding protein-1) mRNA [14]. The excision of a $26 \mathrm{nt}$ sequence of $X B P 1 \mathrm{mRNA}$ results in a frame-shift and the translation of spliced XBP1 (XBP1s), which functions as a potent transactivator of UPR target genes, cooperating with ATF6. In addition, protracted ER stress results in the activation of a further IRE1 endoribonuclease mechanism, termed RIDD (regulated IRE1dependent decay) [15]. RIDD results in the selective degradation of ER-associated mRNAs thereby decreasing the translational burden of the ER. ATF6, with its two isoforms a and $\beta$, is a type II ER transmembrane molecule that encodes a bZIP transcriptional activator in its cytoplasmic domain. Upon sensing misfolded proteins, ATF6 (or ATF6p90) is processed first via site-1 protease (S1P) followed by site-2 protease (S2P) within the Golgi apparatus, which releases its cytoplasmic domain (ATF6f or ATF6p50) that translocates to the nucleus and transactivates its target genes $[10,11]$. Finally, PERK is a type I ER transmembrane protein kinase that, upon sensing ER stress, inhibits general protein translation into the ER through inactivation of the initiation factor elongation initiation factor $2 a$ (eIF2a) via serine phosphorylation. This translational attenuation helps alleviate ER stress. In addition to this function of PERK/eIF2a, eIF2 $a$ phosphorylation also leads to preferential increases in the translation of selective mRNAs which contain inhibitory upstream open reading frames (uORFs) within the $5^{\prime}$ untranslated region (UTR) which normally preclude their translation in the steady state $[10,11]$. Via this mechanism, PERK/eIF2 $a$ activation results in the translation of ATF4 (activating transcription factor 4), which in turn upregulates a further subset of UPR genes. While ATF4 preferentially transactivates genes involved in amino acid transport, resistance to oxidative stress and glutathione biosynthesis, ATF6f and XBP1s cooperate to transactive genes involved in ER associated degradation (ERAD) and protein folding. XBP1s is further involved in transactivating genes important for protein entry into the ER, and via enzymes related to phospholipid biosynthesis it is involved in the biogenesis of the ER and Golgi [10,11]. Notably, XBP1s-regulated target genes can be separated into a group of core UPR genes that are shared among a variety of cell types and conditions; and a remarkably diverse set of target genes that are transactivated in a cell type- and conditiondependent manner [16]. The underlying mechanism of this dichotomy is not entirely understood at the moment, but might explain the remarkably different function of XBP1 in 
different cell types as revealed through cell-specific genetic ablation. In case these integrative adaptive mechanisms aimed at resolving ER stress fail, protracted and severe ER stress can induce apoptosis.

\section{Mechanistic insight into the role of the UPR in gastrointestinal disease}

\subsection{IRE1/XBP1 signaling in IECs}

At baseline, small and large intestinal IECs exhibit very little IRE1 activity as revealed through the presence of minute quantities of spliced XBP1 under homeostatic conditions [17-19]. A $C r e$ reporter cloned in-frame with $X b p 1 s$, whereby Cre recombinase activates a fluorescent reporter in cells with $X b p 1$ splicing activity (i.e. IRE1 activation), identified Paneth cells at the crypt base and small intestinal villus IECs as a site of active Xbp1 function [20].

The first insight into the importance of the IRE1/XBP1 branch of the UPR in IECs and the intestine in general came from studies of $\operatorname{Ire} 1 \beta^{-/-}\left(\mathrm{Ern}^{-/-}\right)$mice [13]. As noted above, Ire1 $\beta$ is specifically expressed in the intestinal and respiratory epithelium. Although $\operatorname{Ire} 1 \beta^{-/-}$mice do not exhibit any gross or microscopic anomalies, increased expression of grp78 (BiP) can be detected in epithelial cells of the stomach, small intestine and colon in these mice, indicative of ER stress. This was shown to be associated with increased sensitivity to experimental colitis induced by the barrier disruptive reagent dextran sodium sulphate (DSS) (Figure 1, Table 1).

Introduction of a premature stop codon close to the $N$-terminus of XBP1, hence affecting XBP1u and XBP1s, by conditional deletion of only one allele of exon 2 of Xbp1 in IECs via a Villin-promoter $C r e$ transgene was sufficient to induce massive splicing of $X b p 1$ mRNA (the splicing site is encoded from exon 4 and therefore retained for analysis) [18]. Along with the low abundance of XBP1s in the steady state, this indicates a very high sensitivity of IECs toward ER stress caused by even minor perturbations of XBP1 effector function. Although expression of the ER chaperone grp78 is to a substantial extent under the control of Xbp1, $\mathrm{Xbp1}^{-/-(I E C)}$ mice nonetheless exhibited increased grp78 expression indicative of ER stress [18]. As a consequence of ER stress in IECs, mature Paneth cells were depleted. Remnant Paneth cells exhibited an absence of the typically expanded ER in Paneth cells and only few and small granules compared to the extensive granule compartment observed on XBP1-sufficient Paneth cells. As a consequence, $X b p 1^{-/(I E C)}$ mice possess decreased crypt bactericidal function and a consequent impairment in bacterial handling of model pathogens such as Listeria monocytogenes [18]. Similar cell biological alterations were also observed in goblet cells in $X b p 1^{-/(I E C)}$ mice, together with an approximately $30 \%$ reduction in their numbers. Furthermore, hypomorphic XBP1 function also resulted in an inflammatory hyperreactivity of IECs towards microbial (e.g. the TLR5 ligand flagellin) or cytokine (e.g. $\mathrm{TNFa}$ ) stimuli, which was characterized by the induction of increased phosphorylation of cJun N-terminal kinase (JNK) and secretion of the neutrophil-attractant chemokine CXCL1 [18]. Increased apoptosis of the small intestinal epithelium as a consequence of unresolved ER stress in association with increased C/EBP homologous protein (CHOP; encoded by Ddit3) expression was further noted. These multiple consequences of XBP1 hypofunction in the intestinal epithelium are associated with the spontaneous development of small intestinal inflammation that is histologically similar to inflammatory bowel disease (IBD) in that it presents with crypt abscesses, neutrophil and mononuclear cell infiltration, and ulcerations [18]. While the colon does not exhibit spontaneous inflammation, $X b p 1^{-/(I E C)}$ mice are more susceptible to DSS colitis compared to $X b p 1^{+/+(I E C)}$ littermates. Of note is that both, spontaneous enteritis as well experimental colitis induced by DSS, exhibited a gene dosage effect with $X b p 1^{+/-(I E C)}$ mice demonstrating a phenotype intermediate between $X b p 1^{+/+(I E C)}$ and $X b p 1^{-/(I E C)}$ mice [18]. Overactivation of IRE1 might play an important 
role in the development of this phenotype as a consequence of hypomorphic XBP1 function, as even deletion of one $X b p 1$ allele was sufficient to cause massive splicing of $X b p 1$ mRNA. IRE1a recruits several adaptor proteins and receptors, such as TRAF2 (TNF receptor associated factor 2), ASK1 (apoptosis signal-regulating kinase 1, encoded by Map3k5), BAX (BCL2-associated X protein), BAK (BCL2-antagonist/killer 1), TNFR1 (tumor necrosis factor receptor type 1, encoded by Tnfrsf1a), to form an UPRsome which can connect the UPR to inflammatory and apoptotic signalling [14, 21-24]. It might similarly be speculated therefore that genetic deletion of IRE1 $\beta$ as alluded to in the previous paragraph might result in insufficient UPR induction, which as a consequence may result in a similar overactivation of the remaining IRE1 isoform, IRE1a. This in turn would also be reflected in increased grp78 expression as observed in Ire $1 \beta^{-/-}$mice.

However, IRE1 $\beta$ also exhibits biological functions that appear to be independent of ER stress. Specifically, IRE1 $\beta$ negatively regulates chylomicron secretion in the intestinal epithelium [25]. Chylomicrons are large vesicles that are formed in the ER from intestinally absorbed fat and fat-soluble vitamins and secreted by the intestinal epithelium.

Apolipoprotein B (apoB) lipidation by microsomal triglyceride transfer protein (MTP), an ER-resident chaperone, represents the rate-limiting step in chylomicron biosynthesis [26]. High-cholesterol and high-fat diets decrease Ire $1 \beta$ mRNA in wild-type mice, and Ire $1 \beta^{--}$ mice that were fed such a diet secreted more chylomicrons from their IECs and developed more severe hyperlipidemia. This was due to IRE1 $\beta$-, but not IRE1 $\alpha-$, dependent posttranscriptional decay of MTP mRNA [25]. Interestingly, while IRE1 $\beta$ is not expressed in the liver where apoB-containing VLDL (very low density lipoprotein) particles are secreted in an MTP-dependent fashion, IRE1a exerts a similar profound effect on lipid metabolism in the liver [27-30]. The regulation of MTP function by IRE1 $\beta$ in IECs is also interesting from the perspective of the inflammatory phenotype observed in $X b p 1^{-/-(I E C)}$ mice, since MTP is co-opted by the immune system to transfer antigenic lipid onto the nascent grove of CD1d [31-33] (and other CD1 molecules [34]). CD1d is expressed on a variety of cells including IECs and dendritic cells (DCs) [35], and CD1d-restricted antigen presentation plays a major role in oxazolone colitis, a hapten-induced model of human ulcerative colitis that is mediated by CD1d-restricted, invariant natural killer T cells [31, 36]. Indeed, a small IEC line with decreased XBP1 expression through RNA interference exhibits increased CD1drestricted antigen presentation in vitro suggesting increased MTP and/or CD1d function when XBP1 function is hypomorphic [18].

\subsection{Anterior gradient 2 (AGR2) in IEC homeostasis}

AGR2 is an ER-resident protein disulfide isomerase (PDI) originally discovered in a screen for mRNAs selectively expressed in intestinal goblet cells [37]. It is also expressed in other secretory IECs such as Paneth cells and enteroendocrine cells, and also in MSI1 ${ }^{+}$ (Musashi-1) intestinal progenitor cells, with the highest expression noted in the ileum and colon [38, 39]. PDIs are a family of at least 19 thioredoxin-like domain-containing proteins critical for formation of correctly arranged disulfide bonds in proteins within the ER [40]. As already alluded to above, goblet cells secrete abundant quantities of mucus into the intestinal lumen that consists primarily of MUC2 which forms a net-like polymer [6, 41]. The large protein size of MUC2 (> 5000 aa) is a challenge for the ER and the Golgi apparatus of goblet cells and also Paneth cells where it is processed as it involves extensive $O$-glycosylation of central mucin repeats and intra- and inter-chain disulfide bond formation in the cysteine-rich $N$ - and $C$-terminal domains [6, 42]. Glycosylated, folded and multimerized mucins then enter secretory granules, from which they are released in the lumen. AGR2 is critically required for MUC2 mucin production in vivo, and in its absence, the intestinal epithelium exhibits profoundly increased expression of ER stress markers such as grp78 and $\mathrm{Xbp} 1$ splicing, together with increased expression of pro-inflammatory 
cytokines $[19,38]$. The increased production of inflammatory mediators in the context of unabated ER stress is a common theme in the intestinal epithelium as also observed in $X b p 1^{-/-(I E C)}$ mice (see above). Consistent with this, silencing of $A g r 2$ expression in a pancreatic cancer cell line increased ER stress induced by tunicamycin [19]. Importantly, Agr $2^{-/}$mice spontaneously develop severe ileocolitis characterized by multinucleated giant cells reminiscent of the granulomatous inflammation observed in human Crohn's disease (CD) [19]. Spontaneous ileocolitis was preceded by marked expansion in the Paneth cell compartment located at the bottom of small intestinal crypts, and mice with a germ-line, but not inducible, deletion of $\mathrm{Agr}_{2}$ also were noted to exhibit abnormally positioned Paneth cells in the villi of the small intestine [19]. Interestingly, an independently generated Agr $2^{-/}$mouse model did not develop spontaneous ileocolitis, despite exhibiting increased colonic expression of pro-inflammatory cytokines and rectal prolapse at very old age [38]. A different gene targeting strategy (exons 2-4 in [19] and exons 2-3 in [38]) and different genetic backgrounds (although both ES cell lines were derived from inbred 129 mice) could account for this difference. However, another intriguing possibility is that differences in the intestinal microbiota could have been the precipitator of the specific phenotypic manifestations in each of these colonies. This notion may be particularly interesting, since the ileocolitic mice were held under conventional conditions, whereas those that did not develop spontaneous disease were maintained in a specific pathogen-free (SPF) environment $[19,38]$. Further characterization of these models and their intestinal microbiota in different environments might therefore be highly informative, and could provide an intriguing paradigm of gene - microbiota interaction and their relation to ER stress.

\subsection{ATF6 signaling and intestinal homeostasis}

The active form of ATF6, generated through S1P and S2P at the Golgi membrane subsequent to sensing misfolded proteins in the ER, is a potent transactivator of UPR target genes, including grp78 (78kDa glucose-regulated protein; also known as BiP [Binding immunoglobulin Protein] and encoded by Haspa5), glucose regulated protein 94 (Grp94) and P58 ${ }^{\mathrm{IPK}}$ (protein kinase inhibitor of $58 \mathrm{kDa}$; encoded by Dnajc3) [12, 14, 43-45]. ATF6 $\beta$ (encoded by $A t f 6 b$ ) is distantly related to ATF6a (encoded by Atf6), albeit both isoforms are ubiquitously expressed. While $A t f 6 a^{-/}$and $A t f 6 \beta^{-/}$single knock-out mice are viable, though sensitive to ER stress, double-knockouts are embryonically lethal, indicating functional redundancy during embryonic development [46]. Although wild-type bone marrow-reconstituted Atf6a ${ }^{-/-}$mice (to allow studying the role of ATF6a in nonhematopoietic cells, hence in inference primarily in colonic epithelium) do not develop spontaneous intestinal inflammation, they are exquisitely sensitive to DSS colitis [47]. During the course of DSS colitis in wild-type mice, colonic IECs develop ER stress, reflected by increased expression grp78, ATF4, CHOP and spliced XBP1, coinciding with the development of colitis [47]. This ER stress response was impaired in $A t f 6 a^{-/}$mice reconstituted with wild-type bone marrow, and these mice exhibited decreased expression of the ER chaperones grp78, grp94 and P58 ${ }^{\mathrm{IPK}}$ compared to bone-marrow reconstituted Atf6a $\mathrm{a}^{+/}$mice, which also resulted in increased apoptosis in the colonic epithelium [47]. The impaired upregulation of $\mathrm{P} 58^{\mathrm{IPK}}$, an ER resident chaperone belonging to the DNAJ chaperone family which is involved in proper protein folding [48, 49], in and of itself is of particular relevance for the development of the increased severity of DSS colitis observed. $P 58^{I P K-/-}$ mice reconstituted with wild-type bone marrow develop more severe mucosal damage, loss of goblet cells and denser inflammatory infiltration compared to heterozygous littermate controls [47]. P58 $8^{\mathrm{IPK}}$ deletion results in a stressed ER in colonic IECs, characterized by increased expression of grp78 and increased phosphorylation of IRE1a, together with induction of pro-apoptotic CHOP [47]. 
Further evidence points towards the contribution of this branch of the UPR in mediating susceptibility to experimental colitis. Using a forward-genetic approach with $N$-ethyl- $N$ nitrosourea (ENU) mutagenesis, missense mutations in S1P (Mbtps 1, membrane-bound transcription factor peptidase site 1) in a mouse model termed woodrat have been discovered that increase the susceptibility to DSS colitis [50]. These mice exhibited diminished levels of colonic grp78 and grp94 expression upon DSS administration [50]. Experiments with bone-marrow chimeric mice pointed to non-hematopoietic cells as the origin of the woodrat phenotype, hence inferring a role of intestinal epithelial cells. In addition to ATF6 $a$ and $\beta$, $\mathrm{S} 1 \mathrm{P}$ is also involved in the activation of other bZIP transcription factors, such as CREBH (CRE-binding protein $\mathrm{H}$ ), OASIS (old astrocyte specifically induced substance), lZIP (leucine zipper protein), BBF2H7 (box B-binding factor 2 human homolog on chromosome 7), CREB4 (CRE-binding protein 4) [50,51]. These could also contribute to the colitic phenotype observed in the woodrat mouse model, albeit the overlap in ER stress chaperone regulation in woodrat and Atf6a ${ }^{-/-}$mice makes an ATF6-dependent mechanism involving the UPR most likely as other S1P-activated transcription factors are less closely mechanistically linked to the UPR.

\subsection{The PERK/elF2 $\alpha /$ ATF4/CHOP branch of the UPR and gastrointestinal disease}

As already alluded to above, the CCAAT/enhancer-binding protein (C/EBP) homologous protein (CHOP) is induced in the colitis observed in XBP1-, ATF6a-, and P58 $8^{\mathrm{IPK}_{\text {-deficient }}}$ mice, indicative of activation of the PERK/eIF2a branch of the UPR due to ER stress. CHOP has an important role in inducing apoptosis in cells that exhibit unabated ER stress [14]. Indeed, Chop ${ }^{-/-}$mice are protected from DSS colitis, which is associated with a decrease of apoptotic cells observed during colitis [52]. Chop ${ }^{-/-}$mice were similarly protected from colitis induced by trinitrobenzene sulfonic acid (TNBS) [52], a hapteninduced colitis model [53]. In light of the importance of IL-23R signaling for the evolution of intestinal inflammation in IBD [54-57], it is notable that CHOP markedly enhances TLRinduced IL-23 production in myeloid cells via increased binding of CHOP to the II23p19 promoter under conditions of ER stress [58].

\subsection{Missense mutations in Muc2 and spontaneous colitis}

An ENU-induced forward genetic screen has revealed two notable mouse models with spontaneous colitis resembling human UC, which are caused by two independent missense mutations in the Muc2 gene [59]. These mutant mice (Winnie and Eeyore) exhibit evidence of altered MUC2 biosynthesis with accumulation of MUC2 precursor, and a decrease in stored, properly glycosylated mucin in goblet cell granules. This was accompanied by ultrastructural and biochemical (grp78, XBP1 splicing) evidence of ER stress [59]. The causative missense mutations locate to the MUC2 oligomerization domain, and in vitro transfection studies of normal and variant oligomerization domains indicated that the associated misfolding caused ER stress. This is a very interesting model of spontaneous pathology, albeit it is inherently complex to tease out the relative contribution of ER stress in goblet cells, and the contribution of a diminished mucus layer to disease pathology, since $\mathrm{Muc}^{-/-}$mice also develop spontaneous colitis [60].

\subsection{HLA-B27 and the UPR}

Individuals with the human class I major histocompatibility allele HLA-B27 are at significant risk for developing spondyloarthritis, a systemic inflammatory condition not only involving joints, but also inflammation of the small intestine among other immune phenomena [61]. HLA-B27/human $\beta_{2}$-microglobulin transgenic rats recapitulate the human disease as they develop spondyloarthritis and peripheral arthritis, ileitis, and further inflammatory lesions in the genital tract, skin, nails and heart [62]. Classical MHC Irestricted CD8a $\beta^{+} \mathrm{T}$ cells do not appear to be required for pathogenesis as their depletion 
has no effect on arthritis or gastrointestinal inflammation in HLA-B27/ $\beta_{2} \mathrm{~m}$ transgenic rats [63]. Notably, the UPR is activated in macrophages from HLA-B27/ $\beta_{2} \mathrm{~m}$ transgenic rats, implying that HLA-B27 misfolding, which HLA-B27 is inherently prone to, induces ER stress [64]. Induction of the UPR in myeloid cells from HLA B27/ $\beta_{2} m$-transgenic rats results interestingly in increased IL-23 expression upon stimulation with the TLR4 ligand LPS, and indeed IL-23 expression is increased in colonic tissue of transgenic rats concurrently with the development of intestinal inflammation [65]. This was associated with increased IL-17 expression, a downstream target of IL-23, in CD4 ${ }^{+} \mathrm{T}$ cells [65]. Altogether these data suggest a possible link of HLA-B27 with intestinal inflammation on the basis of increased IL-23 expression due to an activated UPR consequent to HLA-B27 misfolding. Whether this is CHOP-mediated remains to be defined [58].

\section{ER stress and activation of the UPR in human gastrointestinal tissue}

Evidence of unresolved ER stress and an activated UPR in IECs has been reported in both forms of IBD, Crohn's disease (CD) and ulcerative colitis (UC) [18, 59, 66-68], obesity [69], HIV/AIDS [70], and during the course of injury associated with ischemia/reperfusion [71].

With regard to IBD, evidence of ER stress has been reported in IECs isolated from both inflamed and non-inflamed regions of the small and large intestine in patients with $\mathrm{CD}$ and UC $[18,59,66-68]$. In CD, increased grp78 expression and $X B P 1$ splicing was noted in intestinal biopsies [18,68], and grp78 localized to small intestinal and colonic IECs on immunohistochemistry [68]. In the latter study, ER stress in IECs was associated with downregulation of the xenobiotic transporter ATP-binding cassette G2 (ABCG2) from the cell surface [68]. Another in-depth study has analyzed IECs from non-inflamed tissues of patients with UC [67]. In this context, colonic IECs exhibited substantially increased XBP1 splicing, indicative of increased IRE1 activity, together with increased expression of Grp78, Grp94 and EDEM1 (ER degradation enhancer, mannosidase alpha-like 1), and increased cleavage of ATF6a to its transcriptionally active p50 form compared to IECs obtained from healthy control patients [67]. These findings were accompanied by an expansion of the ER surface area as revealed through transmission electron microscopic studies [67]. Altogether, these results indicate massive ER stress in the UC epithelium, even in the non-inflamed state. Considering that only a small fraction of IBD patients are predicted to harbor riskconferring polymorphisms in UPR and ER stress-related genes [18, 56, 72], it is remarkable that all non-inflamed UC biopsies studied exhibited ER stress, while none of the control subjects did [67], implying unresolved ER stress as a general feature of the UC epithelium. Notably, while the aforementioned data indicate activation of the IRE1/XBP1 and ATF6 branches of the UPR, phosphorylation of eIF2a was observed to be decreased in UC epithelium compared to healthy controls [67]. This was accompanied by decreased ATF4 and CHOP, and increased GADD34 (growth arrest and DNA damage-inducible protein 34, encoded by Ppp1r15a) expression in UC compared to healthy controls, implying a selective hypomorphic activation of the eIF2a/ATF4/CHOP branch of the UPR in UC [67]. However, circumstantial evidence presented in this paper suggested that hypomorphic eIF2a activation was not necessarily a consequence of decreased PERK activation [67]. The suspected consequent deregulation of protein translation initiation was reflected in alterations in mRNAs actively translated from polysomes [67]. The mechanistic basis and functional importance of this selective hypomorphic eIF2 $a$ activation in the context of overt ER stress in the UC epithelium is currently unclear.

Of further note in this context is also the regulation of the chaperone grp96, one of the most abundant ER proteins, which is specifically involved in the folding, assembly and export of specific proteins in the ER, including Toll-like receptors (TLRs) and as such involved in 
innate immunity toward pathogens [73]. The ER stressed intestinal epithelium of the ileum in $\mathrm{CD}$ exhibits strong expression of grp96 at the apical plasma membrane together with CEACAM6 (carcinoembryonic antigen-related cell adhesion molecule 6), where it is essential for the invasion of adherent-invasive Escherichia coli (AIEC) [74]. AIEC can adhere and invade the intestinal epithelium, and are preferentially found in patients with $\mathrm{CD}$, where they colonize the ileal mucosa [75]. Thus, ER stress may result in an intestinal epithelium that is more prone to binding pro-inflammatory pathobionts such as AIEC which serve to further promote the activity of the disease.

Apart from IBD, an activated UPR in IECs, in particular Paneth cells, has been demonstrated in obesity [69]. The authors were initially prompted to investigate Paneth cells for their antimicrobial function because of some notable similarities in the alterations found in the intestinal microbiota (i.e. increase in Firmicutes over Bacteroidetes) in obesity and IBD compared to healthy, normal weight individuals. Interestingly, Paneth cells of severely obese subjects contained decreased levels of human a-defensin 5 (HD5, encoded by $D E F A 5$ ) and lysozyme protein compared to normal weight subjects, despite unaltered mRNA expression of both transcripts [69], implying a translational block. Indeed, Paneth cells from severely obese patients exhibited ultrastructural and biochemical evidence of ER stress, reflected by increased grp78 and ATF4 expression compared to normal weight subjects [69]. Furthermore, grp78 expression in Paneth cells was inversely correlated with lysozyme protein expression [69]. These observations fit very well with the long known activation of the UPR and unresolved ER stress in the obese liver, which regulates insulin sensitivity [76].

Finally, UPR induction has also been implicated in the mechanisms that lead to intestinal leakiness during the course of ischemia/reperfusion injury in the intestine. In an interesting experimental system of jejunal ischemia/reperfusion injury in patients undergoing pancreaticoduodenectomy, ER stress in Paneth cells was observed as deduced from evidence for increased expression of grp78, CHOP and GADD34, and increased splicing of XBP1 mRNA [71]. This was associated with increased apoptosis of Paneth cells. Recapitulating this model system in Sprague-Dawley rats, ER stress-associated Paneth cell loss, or cytotoxic depletion of Paneth cells through administration of dithizone, which complexes with zinc found in high concentrations in their granules [77], were associated with increased bacterial translocation and elevated circulating levels of TNFa and IL-6 [71]. These data suggest that ER stress-associated Paneth cell loss may be an important contributor to the leakiness of the intestine after ischemia/reperfusion injury. ER stress might also contribute to the leakiness of the intestine in human immunodeficiency virus (HIV) infection and the acquired immunodeficiency syndrome (AIDS). Specifically, duodenal biopsies from patients with HIV and AIDS display increased levels of XBP1s and CHOP expression, along with increased IL-1 $\beta$, CD3 $\varepsilon$ and HLA-DR expression, and IECs exposed to HIV-1 Vpr results in a similar UPR activation together with pro-inflammatory gene expression [70]. It might be speculated that ER stress mechanisms might contribute to the leakiness of the intestine in AIDS patients, which exhibit a pattern of serological markers of bacterial translocation very similar to that described in CD [78]. Of additional note, specific HIV protease inhibitors used in the treatment of HIV can induce ER stress in the intestinal epithelium and thereby might also disrupt barrier integrity [79].

\section{Genetic evidence for involvement of ER stress-related mechanisms in human gastrointestinal tissue}

Genetic association studies have revealed several genetic loci that are significantly associated with risk for $\mathrm{CD}$ and UC (Figure 1, Table 1). A candidate gene study prompted by the spontaneous enteritis arising in $X b p 1^{--(I E C)}$ mice that surveyed the $X B P 1$ locus and 
its wider vicinity revealed an association signal for this locus for IBD, which was replicated in two further panels, and thereby confirmed the association with CD and UC [18]. The lack of linkage disequilibrium at the larger $X B P 1$ locus suggested that the locus association signal might be based on individual rare variants. A deep sequencing experiment of the coding region of $X B P 1$ and its promoter revealed an approximately 3 -fold larger number of rare single nucleotide polymorphisms (SNP) at this locus in IBD patients compared to healthy controls [18]. Among those were non-synonymous (ns) SNPs which only occurred in IBD and not in healthy controls. Two of those were functionally characterized via transfection of wild-type and mutant expression vectors into IEC lines or $\mathrm{Xbp}^{-/-}$mouse embryonic fibroblasts (MEFs) [18]. These IBD-only variants resulted in decreased induction of UPR target genes, while a further nsSNP variant that occurred at similar frequency in healthy controls and IBD patients was indistinguishable from the wild-type variant in inducing UPR target genes [18]. Altogether, these data indicated that the XBP1 locus was an IBD risk locus, with rare variants constituting the basis for this association signal. The hypomorphic character of these rare variants fit mechanistic insights gleaned from mice with hypomorphic $X b p 1$ function in IECs, which develop spontaneous ileitis/enteritis [18]. Furthermore, the mouse model showed that deletion of one Xbp1 allele in IECs in vivo is sufficient to cause spontaneous enteritis as well as profound induction of ER stress as revealed through the massive hyperactication of IRE1 endoribonuclease activity [18]. This suggests that even minor reductions in XBP1 function might have major effects on IEC function through this mechanism.

A further genetic association that was revealed through a candidate gene study is $A G R 2$, which was also found to be associated with CD and UC [80]. As noted above, $A g r 2^{-/-}$mice exhibit ER stress in their intestinal epithelium and develop ileocolitis with characteristic granuloma-like features.

Finally, an association between Orosomucoid-like 3 (ORMDL3) and the risk for developing $\mathrm{CD}$ [81] and UC [82] has been uncovered through unbiased genome-wide association studies (GWAS). Interestingly, ORMDL 3 is also associated with asthma and type 1 diabetes mellitus [83-85]. ORMDL3 is an ER resident transmembrane molecule primarily expressed in epithelial cells [86], which affects the UPR, although its exact role is not yet entirely clear. Transfection of ORMDL3 into lung epithelial cells selectively activated ATF6a, which consequently transactivated SERCA2b (sarcoplasmic/endoplasmic reticulum calcium ATPase 2, encoded by Atp2a2) transcription, which is important in airway remodeling [86]. In this model system, the other branches of the UPR were not activated by ORMDL3 overexpression. In bronchial epithelial cells, ORMDL3 expression was substantially increased by Th2 cytokines in a STAT6-dependent manner [86]. A further study in human embryonic kidney cell line HEK293T suggested that ORMDL3 binds and inhibits the sarcoendoplasmic reticulum $\mathrm{Ca}^{2+}$ pump (SERCA), which results in reduced $\mathrm{ER} \mathrm{Ca}^{2+}$ concentrations and an increased UPR manifested by increased phosphorylation of eIF2a [87]. Increased IRE1 activity was not present as $X B P 1$ mRNA splicing remained unaltered upon overexpression of ORMDL3 [87]. In contrast to these observations, another study reported that overexpression of ORMDL3 in HEK293T cells decreased basal and tunicamycin-induced UPR, whereas ORMDL3 silencing resulted in an exaggerated UPR after tunicamycin stimulation as deduced from binding assays to a cis-acting UPR element (UPRE) reporter specific for ATF6 [82, 88]. The biological function of ORMDL3 in the ER is complex, as it also acts as a negative regulator of sphingolipid production via formation of a complex with serine palmitoyltransferase, the rate-limiting step in sphingolipid biosynthesis [89]. The exact role of ORMDL3 in IBD clearly needs further study in relevant model systems. 
In concluding this discussion of genetic risk factors in IBD that are associated with factors involved in the UPR, it is important to mention HLA-B27. Specific HLA-B27 subtypes are associated with risk for developing spondyloarthropathies, which are often associated with mucosal inflammation in the ileum [90].

\section{Points of therapeutic intervention}

Considering that IECs appear particularly susceptible to ER stress, and impairment in the UPR in IECs can lead to intestinal inflammation, therapeutic intervention appears as an attractive strategy. Indeed, small molecule chaperones, such as tauro-ursodeoxycholic acid (TUDCA) and 4-phenyl butyrate (PBA), have been reported that contribute to proper protein folding in the ER and thus alleviate ER stress. The study of such compounds has been pioneered in the field of obesity and insulin resistance [91, 92], and aspects related to therapeutic manipulation of ER stress are extensively discussed in Ozcan and colleagues in this review series [93].

The utility of TUDCA and PBA has also been investigated in models of intestinal inflammation. TUDCA and PBA have been demonstrated to alleviate ER stress in the colonic epithelium in DSS colitis, which was associated with amelioration of intestinal inflammation in the colon [47]. Treatment with either compound also alleviated the more severe course of DSS colitis observed in $A t f 6 a^{-/}$and $P 58^{I P K-/-}$ mice reconstituted with wild-type bone marrow, implying indeed an ER stress-mediated mechanism underlying the more severe disease course and specifically an important role for ER stress and therapeutic targeting of the intestinal epithelium [47]. Finally, in $1110^{-/}$mice that received piroxicam for the induction of colitis, TUDCA or PBA treatment similarly ameliorated experimental disease [47]. Altogether, these data indicate that small molecular chaperones may be efficient in alleviating ER stress, thereby decreasing experimentally-induced intestinal inflammation. Based on the notion that IECs are particularly important for ER stressassociated intestinal inflammation, topical treatment at the inner body surface via local delivery may represent an attractive treatment paradigm to minimize systemic effects of these drugs.

In this context it is noteworthy that the ileal epithelium is naturally exposed to TUDCA, a tertiary bile salt [94]. TUDCA is a taurine conjugate of UDCA, though the latter appears to be substantially more potent in alleviating ER stress in IECs [94]. In contrast to UDCA, which is substantially more lipophilic and thereby can seamlessly traverse biological membranes including the ER, TUDCA requires active cellular uptake via the ileal bile acid:sodium symporter [94]. UDCA is currently in common clinical use in cholestatic liver diseases, primary biliary cirrhosis and primary sclerosing cholangitis, and it might be speculated that part of the long-known efficacy of this compound might be related to alleviation of ER stress. However, bile acids have multiple other biological functions independent of ER stress alleviation, which could also contribute to their clinical efficacy [95].

\section{Concluding remarks}

The UPR is a critical component of IEC homeostasis in the intestine, and impairment can lead to the original initiation of intestinal inflammation as observed in IBD (Figure 1, Table 1). While genetic impairment of UPR-related mechanisms has been well documented, our understanding of environmental, microbial and dietary factors that impact on UPR function in the intestine is only beginning to develop.

Specific bacterial toxins can activate (e.g. Shiga toxin subAB proteolytically cleaves grp78 and thereby activates all three branches of the UPR [96-98]) and inhibit (e.g. trierixin, 
which inhibits XBP1 splicing $[99,100])$ the UPR. Given this, it is highly likely that many more bacterial metabolites might affect UPR function and remain to be elucidated. One example might be the microbial metabolism of bile acids such as TUDCA and UDCA associated with microbial dysbiosis in IBD [101], which might determine the availability of endogenous 'ER stress relievers' at the mucosal surface. Dietary intake might also have an important influence on the IECs capacity to withstand ER stress with the notion that there are dietary agents which enhance or inhibit UPR function and thus are either beneficial or deleterious to the intestinal epithelium, respectively. One example is glutamine, which has been shown to alleviate ER stress in the epithelium and decrease the severity of TNBS colitis in rats [102]. Specifically, glutamine decreased ATF6, ATF4, and CHOP expression, along with decreased IRE1 phosphorylation and XBP1 splicing, which was associated with decreased induction of apoptosis in IECs [102]. A further example is related to the oral intake of iron [103]. In the $T n f^{\triangle A R E}$ model of spontaneous ileitis, changing from a regular murine chow diet to an iron sulfate-free diet protected from intestinal inflammation, which was associated with alleviation of ER stress and pro-apoptotic mechanisms in IECs [103]. Interestingly, ER stress in the IEC line MODE-K increased their susceptibility to the cytotoxic effector function of $\mathrm{T}$ cells from $T n f^{\triangle A R E}$ mice. Since the change in diet had a profound impact on the composition of the intestinal microbiota [103], the exact cause-effect relationship of the beneficial effects of an iron sulfate-free diet with regard to ER stress, direct anti-inflammatory mechanisms, and microbial effects are hard to discern.

Nonetheless, these examples highlight the variety and substantial importance of non-host factors that impact on the UPR in IECs in the intestine. These 'non-host' factors that directly or indirectly impact on the UPR could potentially constitute the mechanistic basis for why ER stress appears to be a very common and typical feature of IBD IECs even in the noninflamed state [18], in particular in UC [67].

An innate immune response is per se an important, and evolutionary conserved, inducer of ER stress, as elegantly demonstrated in C. elegans [104]. Considering the massive induction of protein synthesis associated with inflammatory mediator secretion as a consequence of innate immune activation of cells, which may arise from a bona fide microbial signal or as part of an early innate immune signal of the host (e.g. pro-inflammatory cytokines), such a requirement for an efficient UPR may appear unsurprising indeed [105]. Consistent with this, in IECs pro-inflammatory cytokines such as TNFa, induce, and anti-inflammatory cytokines such as IL-10 inhibit ER stress [66]. This requirement for an efficient UPR as an integral part of an innate immune mechanism might not only be relevant for IECs, but appears also to be relevant for CD8a $\beta^{+}$intraepithelial lymphocytes (IELs), and which exhibit attenuated granzyme B-dependent cytotoxicity when grp78 is rendered hypomorphic [106]. For these reasons, ER stress-related mechanisms in IECs (and potentially IELs and other immune cells) may therefore also play an important role in perpetuating intestinal inflammation arising from a variety of different pathophysiological pathways and as a corollary be associated with the development of colorectal neoplasia; a major sequelae of these diseases. In conclusion, the UPR plays a fundamentally important role in the intestine, in particular within the intestinal epithelium, where it integrates host, microbial and environmental signals, and contributes to the pathophysiology of IBD.

\section{Acknowledgments}

Work in the authors' laboratories has been supported by the European Research Council under the European Community's Seventh Framework Programme (FP7/2007-2013)/ERC Grant agreement n 260961; the National Institute for Health Research Cambridge Biomedical Research Centre; the Addenbrooke's Charitable Trust (all A.K.); NIH grants DK044319, DK051362, DK053056, DK088199, and the Harvard Digestive Diseases Center (HDDC) (DK0034854) (all R.S.B.); 


\section{Abbreviations}

ER

UPR

IBD

IEC

IRE1

PERK

ATF6

XBP1

eIF2 $a$

RIDD

S1P

S2P

UORF

UTR

ATF4

ATF6

ERAD

DSS

JNK

C/EBP

CHOP

TNF

TRAF2

ASK1

BAX

BAK

TNFR1

MTP

VLDL

AGR2

MSI1

SPF

grp78

BiP

Grp94 endoplasmic reticulum

unfolded protein response

inflammatory bowel disease

intestinal epithelial cell

inositol-requiring enzyme 1

Protein Kinase Related-like ER kinase

Activating transcription factor 6

$\mathrm{X}$-box binding protein-1

elongation initiation factor $2 a$

regulated IRE1-dependent decay

site-1 protease

site- 2 protease

upstream open reading frame

$5^{\prime}$ untranslated region

activating transcription factor 4

activating transcription factor 6

ER-associated degradation

dextran sodium sulfate

Jun N-terminal kinase

CCAAT/enhancer-binding protein

C/EBP homologous protein

tumor necrosis factor

TNF receptor associated factor 2

apoptosis signal-regulating kinase 1

BCL2-associated X protein

BCL2-antagonist/killer 1

tumor necrosis factor receptor type 1

microsomal triglyceride transfer protein

very low density lipoprotein

anterior gradient 2

Musashi-1

specific pathogen-free

$78 \mathrm{kDa}$ glucose-regulated protein

Binding immunoglobulin Protein

glucose regulated protein 94 


\begin{tabular}{|c|c|}
\hline P58IPK & protein kinase inhibitor of $58 \mathrm{kDa}$ \\
\hline ENU & N-ethyl-N-nitrosourea \\
\hline CREBH & CRE-binding protein $\mathrm{H}$ \\
\hline OASIS & old astrocyte specifically induced substance \\
\hline IZIP & leucine zipper protein \\
\hline ВBF2H7 & box B-binding factor 2 human homolog on chromosome 7 \\
\hline CREB4 & CRE-binding protein 4 \\
\hline TNBS & trinitrobenzene sulfonic acid \\
\hline CD & Crohn's disease \\
\hline $\mathbf{U C}$ & ulcerative colitis \\
\hline ABCG2 & ATP-binding cassette G2 \\
\hline EDEM1 & ER degradation enhancer, mannosidase alpha-like 1 \\
\hline GADD34 & growth arrest and DNA damage-inducible protein 34 \\
\hline TLR & Toll-like receptor \\
\hline CEACAM6 & carcinoembryonic antigen-related cell adhesion molecule 6 \\
\hline AIEC & adherent-invasive Escherichia coli \\
\hline HIV & human immunodeficiency virus \\
\hline AIDS & acquired immunodeficiency syndrome \\
\hline MEF & mouse embryonic fibroblast \\
\hline ORMDL3 & orosomucoid-like 3 \\
\hline SERCA2b & sarcoplasmic/endoplasmic reticulum calcium ATPase 2 \\
\hline SERCA & sarco-endoplasmic reticulum $\mathrm{Ca} 2+$ pump \\
\hline TUDCA & tauro-ursodeoxycholic acid \\
\hline PBA & 4-phenyl butyrate \\
\hline UDCA & ursodeoxy-cholic acid \\
\hline IEL & intraepithelial lymphocyte \\
\hline
\end{tabular}

\section{References}

1. Pott J, Hornef M. Innate immune signalling at the intestinal epithelium in homeostasis and disease. EMBO Rep. 2012; 13:684-98. [PubMed: 22801555]

2. van der Flier LG, Clevers H. Stem cells, self-renewal, and differentiation in the intestinal epithelium. Annu Rev Physiol. 2009; 71:241-60. [PubMed: 18808327]

3. Barker N, van Es JH, Kuipers J, Kujala P, van den Born M, Cozijnsen M, et al. Identification of stem cells in small intestine and colon by marker gene Lgr5. Nature. 2007; 449:1003-7. [PubMed: 17934449]

4. Sato T, van Es JH, Snippert HJ, Stange DE, Vries RG, van den Born M, et al. Paneth cells constitute the niche for Lgr5 stem cells in intestinal crypts. Nature. 2011; 469:415-8. [PubMed: 21113151]

5. Rothenberg ME, Nusse Y, Kalisky T, Lee JJ, Dalerba P, Scheeren F, et al. Identification of a Ckit+ Colonic Crypt Base Secretory Cell that Supports Lgr5+ Stem Cells in Mice. Gastroenterology. 2012 
6. Hansson GC. Role of mucus layers in gut infection and inflammation. Curr Opin Microbiol. 2012; 15:57-62. [PubMed: 22177113]

7. Kaser A, Zeissig S, Blumberg RS. Inflammatory Bowel Disease. Annu Rev Immunol. 2010; 28:573-621. [PubMed: 20192811]

8. Pukkila-Worley R, Ausubel FM. Immune defense mechanisms in the Caenorhabditis elegans intestinal epithelium. Curr Opin Immunol. 2012; 24:3-9. [PubMed: 22236697]

9. Kaser A, Blumberg RS. Endoplasmic reticulum stress and intestinal inflammation. Mucosal Immunol. 2010; 3:11-6. [PubMed: 19865077]

10. Walter P, Ron D. The unfolded protein response: from stress pathway to homeostatic regulation. Science. 2011; 334:1081-6. [PubMed: 22116877]

11. Schroder M, Kaufman RJ. The mammalian unfolded protein response. Annu Rev Biochem. 2005; 74:739-89. [PubMed: 15952902]

12. Todd DJ, Lee AH, Glimcher LH. The endoplasmic reticulum stress response in immunity and autoimmunity. Nat Rev Immunol. 2008; 8:663-74. [PubMed: 18670423]

13. Bertolotti A, Wang X, Novoa I, Jungreis R, Schlessinger K, Cho JH, et al. Increased sensitivity to dextran sodium sulfate colitis in IRE1beta-deficient mice. J Clin Invest. 2001; 107:585-93. [PubMed: 11238559]

14. Hetz C, Martinon F, Rodriguez D, Glimcher LH. The unfolded protein response: integrating stress signals through the stress sensor IRE1alpha. Physiol Rev. 2011; 91:1219-43. [PubMed: 22013210]

15. Hollien J, Weissman JS. Decay of endoplasmic reticulum-localized mRNAs during the unfolded protein response. Science. 2006; 313:104-7. [PubMed: 16825573]

16. Acosta-Alvear D, Zhou Y, Blais A, Tsikitis M, Lents NH, Arias C, et al. XBP1 controls diverse cell type- and condition-specific transcriptional regulatory networks. Mol Cell. 2007; 27:53-66. [PubMed: 17612490]

17. Iwawaki T, Akai R, Kohno K, Miura M. A transgenic mouse model for monitoring endoplasmic reticulum stress. Nat Med. 2004; 10:98-102. [PubMed: 14702639]

18. Kaser A, Lee AH, Franke A, Glickman JN, Zeissig S, Tilg H, et al. XBP1 links ER stress to intestinal inflammation and confers genetic risk for human inflammatory bowel disease. Cell. 2008; 134:743-56. [PubMed: 18775308]

19. Zhao F, Edwards R, Dizon D, Afrasiabi K, Mastroianni JR, Geyfman M, et al. Disruption of Paneth and goblet cell homeostasis and increased endoplasmic reticulum stress in Agr2-/- mice. Dev Biol. 2010; 338:270-9. [PubMed: 20025862]

20. Schwitalla S, Fingerle AA, Cammareri P, Nebelsiek T, Goktuna SI, Ziegler PK, et al. Intestinal Tumorigenesis Initiated by Dedifferentiation and Acquisition of Stem-Cell-like Properties. Cell. 2013; 152:25-38. [PubMed: 23273993]

21. Woehlbier U, Hetz C. Modulating stress responses by the UPRosome: a matter of life and death. Trends Biochem Sci. 2011; 36:329-37. [PubMed: 21482118]

22. Hetz C, Bernasconi P, Fisher J, Lee AH, Bassik MC, Antonsson B, et al. Proapoptotic BAX and BAK modulate the unfolded protein response by a direct interaction with IRE1alpha. Science. 2006; 312:572-6. [PubMed: 16645094]

23. Urano F, Wang X, Bertolotti A, Zhang Y, Chung P, Harding HP, et al. Coupling of stress in the ER to activation of JNK protein kinases by transmembrane protein kinase IRE1. Science. 2000; 287:664-6. [PubMed: 10650002]

24. Yang Q, Kim YS, Lin Y, Lewis J, Neckers L, Liu ZG. Tumour necrosis factor receptor 1 mediates endoplasmic reticulum stress-induced activation of the MAP kinase JNK. EMBO Rep. 2006; 7:622-7. [PubMed: 16680093]

25. Iqbal J, Dai K, Seimon T, Jungreis R, Oyadomari M, Kuriakose G, et al. IRE1beta inhibits chylomicron production by selectively degrading MTP mRNA. Cell Metab. 2008; 7:445-55. [PubMed: 18460335]

26. Hussain MM, Fatma S, Pan X, Iqbal J. Intestinal lipoprotein assembly. Curr Opin Lipidol. 2005; 16:281-5. [PubMed: 15891388]

27. Lee AH, Scapa EF, Cohen DE, Glimcher LH. Regulation of hepatic lipogenesis by the transcription factor XBP1. Science. 2008; 320:1492-6. [PubMed: 18556558] 
28. Wang S, Chen Z, Lam V, Han J, Hassler J, Finck BN, et al. IRE1alpha-XBP1s induces PDI expression to increase MTP activity for hepatic VLDL assembly and lipid homeostasis. Cell Metab. 2012; 16:473-86. [PubMed: 23040069]

29. So JS, Hur KY, Tarrio M, Ruda V, Frank-Kamenetsky M, Fitzgerald K, et al. Silencing of lipid metabolism genes through IRE1alpha-mediated mRNA decay lowers plasma lipids in mice. Cell Metab. 2012; 16:487-99. [PubMed: 23040070]

30. Fisher EA, Brodsky JL. The unfolded protein response: a multifaceted regulator of lipid and lipoprotein metabolism. Cell Metab. 2012; 16:407-8. [PubMed: 23040063]

31. Brozovic S, Nagaishi T, Yoshida M, Betz S, Salas A, Chen D, et al. CD1d function is regulated by microsomal triglyceride transfer protein. Nat Med. 2004; 10:535-9. [PubMed: 15107843]

32. Dougan SK, Rava P, Hussain MM, Blumberg RS. MTP regulated by an alternate promoter is essential for NKT cell development. J Exp Med. 2007; 204:533-45. [PubMed: 17312007]

33. Dougan SK, Salas A, Rava P, Agyemang A, Kaser A, Morrison J, et al. Microsomal triglyceride transfer protein lipidation and control of CD1d on antigen-presenting cells. J Exp Med. 2005; 202:529-39. [PubMed: 16087713]

34. Kaser A, Hava DL, Dougan SK, Chen Z, Zeissig S, Brenner MB, et al. Microsomal triglyceride transfer protein regulates endogenous and exogenous antigen presentation by group 1 CD1 molecules. Eur J Immunol. 2008; 38:2351-9. [PubMed: 18624350]

35. Dougan SK, Kaser A, Blumberg RS. CD1 expression on antigen-presenting cells. Curr Top Microbiol Immunol. 2007; 314:113-41. [PubMed: 17593659]

36. Heller F, Fuss IJ, Nieuwenhuis EE, Blumberg RS, Strober W. Oxazolone colitis. a Th2 colitis model resembling ulcerative colitis, is mediated by IL-13-producing NK-T cells. Immunity. 2002; 17:629-38. [PubMed: 12433369]

37. Komiya T, Tanigawa Y, Hirohashi S. Cloning of the gene gob-4, which is expressed in intestinal goblet cells in mice. Biochim Biophys Acta. 1999; 1444:434-8. [PubMed: 10095068]

38. Park SW, Zhen G, Verhaeghe C, Nakagami Y, Nguyenvu LT, Barczak AJ, et al. The protein disulfide isomerase AGR2 is essential for production of intestinal mucus. Proc Natl Acad Sci U S A. 2009; 106:6950-5. [PubMed: 19359471]

39. Wang Z, Hao Y, Lowe AW. The adenocarcinoma-associated antigen, AGR2, promotes tumor growth, cell migration, and cellular transformation. Cancer Res. 2008; 68:492-7. [PubMed: 18199544]

40. Ellgaard L, Ruddock LW. The human protein disulphide isomerase family: substrate interactions and functional properties. EMBO Rep. 2005; 6:28-32. [PubMed: 15643448]

41. Johansson ME, Larsson JM, Hansson GC. The two mucus layers of colon are organized by the MUC2 mucin, whereas the outer layer is a legislator of host-microbial interactions. Proc Natl Acad Sci U S A. 2011; 108 (Suppl 1):4659-65. [PubMed: 20615996]

42. McGuckin MA, Linden SK, Sutton P, Florin TH. Mucin dynamics and enteric pathogens. Nat Rev Microbiol. 2011; 9:265-78. [PubMed: 21407243]

43. Zhang K, Kaufman RJ. From endoplasmic-reticulum stress to the inflammatory response. Nature. 2008; 454:455-62. [PubMed: 18650916]

44. Wang S, Kaufman RJ. The impact of the unfolded protein response on human disease. J Cell Biol. 2012; 197:857-67. [PubMed: 22733998]

45. Back SH, Kaufman RJ. Endoplasmic reticulum stress and type 2 diabetes. Annu Rev Biochem. 2012; 81:767-93. [PubMed: 22443930]

46. Yamamoto K, Sato T, Matsui T, Sato M, Okada T, Yoshida H, et al. Transcriptional induction of mammalian ER quality control proteins is mediated by single or combined action of ATF6alpha and XBP1. Dev Cell. 2007; 13:365-76. [PubMed: 17765680]

47. Cao SS, Zimmermann EM, Chuang BM, Song B, Nwokoye A, Wilkinson JE, et al. The Unfolded Protein Response and Chemical Chaperones Reduce Protein Misfolding and Colitis in Mice. Gastroenterology. 2013

48. Rutkowski DT, Kang SW, Goodman AG, Garrison JL, Taunton J, Katze MG, et al. The role of p58IPK in protecting the stressed endoplasmic reticulum. Mol Biol Cell. 2007; 18:3681-91. [PubMed: 17567950] 
49. Petrova K, Oyadomari S, Hendershot LM, Ron D. Regulated association of misfolded endoplasmic reticulum lumenal proteins with P58/DNAJc3. EMBO J. 2008; 27:2862-72. [PubMed: 18923430]

50. Brandl K, Rutschmann S, Li X, Du X, Xiao N, Schnabl B, et al. Enhanced sensitivity to DSS colitis caused by a hypomorphic Mbtps1 mutation disrupting the ATF6-driven unfolded protein response. Proc Natl Acad Sci U S A. 2009; 106:3300-5. [PubMed: 19202076]

51. Ye J, Rawson RB, Komuro R, Chen X, Dave UP, Prywes R, et al. ER stress induces cleavage of membrane-bound ATF6 by the same proteases that process SREBPs. Mol Cell. 2000; 6:1355-64. [PubMed: 11163209]

52. Namba T, Tanaka K, Ito Y, Ishihara T, Hoshino T, Gotoh T, et al. Positive role of CCAAT/ enhancer-binding protein homologous protein, a transcription factor involved in the endoplasmic reticulum stress response in the development of colitis. Am J Pathol. 2009; 174:1786-98. [PubMed: 19359519]

53. Strober W, Fuss IJ, Blumberg RS. The immunology of mucosal models of inflammation. Annu Rev Immunol. 2002; 20:495-549. [PubMed: 11861611]

54. Hue S, Ahern P, Buonocore S, Kullberg MC, Cua DJ, McKenzie BS, et al. Interleukin-23 drives innate and T cell-mediated intestinal inflammation. J Exp Med. 2006; 203:2473-83. [PubMed: 17030949]

55. Izcue A, Hue S, Buonocore S, Arancibia-Carcamo CV, Ahern PP, Iwakura Y, et al. Interleukin-23 restrains regulatory $\mathrm{T}$ cell activity to drive T cell-dependent colitis. Immunity. 2008; 28:559-70. [PubMed: 18400195]

56. Maloy KJ, Powrie F. Intestinal homeostasis and its breakdown in inflammatory bowel disease. Nature. 2011; 474:298-306. [PubMed: 21677746]

57. Buonocore S, Ahern PP, Uhlig HH, Ivanov II, Littman DR, Maloy KJ, et al. Innate lymphoid cells drive interleukin-23-dependent innate intestinal pathology. Nature. 2010; 464:1371-5. [PubMed: 20393462]

58. Goodall JC, Wu C, Zhang Y, McNeill L, Ellis L, Saudek V, et al. Endoplasmic reticulum stressinduced transcription factor, CHOP, is crucial for dendritic cell IL-23 expression. Proc Natl Acad Sci U S A. 2010; 107:17698-703. [PubMed: 20876114]

59. Heazlewood CK, Cook MC, Eri R, Price GR, Tauro SB, Taupin D, et al. Aberrant mucin assembly in mice causes endoplasmic reticulum stress and spontaneous inflammation resembling ulcerative colitis. PLoS Med. 2008; 5:e54. [PubMed: 18318598]

60. Van der Sluis M, De Koning BA, De Bruijn AC, Velcich A, Meijerink JP, Van Goudoever JB, et al. Muc2-deficient mice spontaneously develop colitis, indicating that MUC2 is critical for colonic protection. Gastroenterology. 2006; 131:117-29. [PubMed: 16831596]

61. Dougados M, Baeten D. Spondyloarthritis. Lancet. 2011; 377:2127-37. [PubMed: 21684383]

62. Hammer RE, Maika SD, Richardson JA, Tang JP, Taurog JD. Spontaneous inflammatory disease in transgenic rats expressing HLA-B27 and human beta $2 \mathrm{~m}$ : an animal model of HLA-B27associated human disorders. Cell. 1990; 63:1099-112. [PubMed: 2257626]

63. May E, Dorris ML, Satumtira N, Iqbal I, Rehman MI, Lightfoot E, et al. CD8 alpha beta T cells are not essential to the pathogenesis of arthritis or colitis in HLA-B27 transgenic rats. J Immunol. 2003; 170:1099-105. [PubMed: 12517979]

64. Turner MJ, Sowders DP, DeLay ML, Mohapatra R, Bai S, Smith JA, et al. HLA-B27 misfolding in transgenic rats is associated with activation of the unfolded protein response. J Immunol. 2005; 175:2438-48. [PubMed: 16081815]

65. DeLay ML, Turner MJ, Klenk EI, Smith JA, Sowders DP, Colbert RA. HLA-B27 misfolding and the unfolded protein response augment interleukin-23 production and are associated with Th17 activation in transgenic rats. Arthritis Rheum. 2009; 60:2633-43. [PubMed: 19714651]

66. Shkoda A, Ruiz PA, Daniel H, Kim SC, Rogler G, Sartor RB, et al. Interleukin-10 blocked endoplasmic reticulum stress in intestinal epithelial cells: impact on chronic inflammation. Gastroenterology. 2007; 132:190-207. [PubMed: 17241871]

67. Treton X, Pedruzzi E, Cazals-Hatem D, Grodet A, Panis Y, Groyer A, et al. Altered endoplasmic reticulum stress affects translation in inactive colon tissue from patients with ulcerative colitis. Gastroenterology. 2011; 141:1024-35. [PubMed: 21699776] 
68. Deuring JJ, de Haar C, Koelewijn CL, Kuipers EJ, Peppelenbosch MP, van der Woude CJ. Absence of ABCG2-mediated mucosal detoxification in patients with active inflammatory bowel disease is due to impeded protein folding. Biochem J. 2012; 441:87-93. [PubMed: 21864296]

69. Hodin CM, Verdam FJ, Grootjans J, Rensen SS, Verheyen FK, Dejong CH, et al. Reduced Paneth cell antimicrobial protein levels correlate with activation of the unfolded protein response in the gut of obese individuals. J Pathol. 2011; 225:276-84. [PubMed: 21630271]

70. Maingat F, Halloran B, Acharjee S, van Marle G, Church D, Gill MJ, et al. Inflammation and epithelial cell injury in AIDS enteropathy: involvement of endoplasmic reticulum stress. FASEB J. 2011; 25:2211-20. [PubMed: 21427211]

71. Grootjans J, Hodin CM, de Haan JJ, Derikx JP, Rouschop KM, Verheyen FK, et al. Level of activation of the unfolded protein response correlates with Paneth cell apoptosis in human small intestine exposed to ischemia-reperfusion. Gastroenterology. 2010

72. Jostins L, Ripke S, Weersma RK, Duerr RH, McGovern DP, Hui KY, et al. Host-microbe interactions have shaped the genetic architecture of inflammatory bowel disease. Nature. 2012; 491:119-24. [PubMed: 23128233]

73. Randow F, Seed B. Endoplasmic reticulum chaperone gp96 is required for innate immunity but not cell viability. Nat Cell Biol. 2001; 3:891-6. [PubMed: 11584270]

74. Rolhion N, Barnich N, Bringer MA, Glasser AL, Ranc J, Hebuterne X, et al. Abnormally expressed ER stress response chaperone Gp96 in CD favours adherent-invasive Escherichia coli invasion. Gut. 2010; 59:1355-62. [PubMed: 20587550]

75. Darfeuille-Michaud A, Boudeau J, Bulois P, Neut C, Glasser AL, Barnich N, et al. High prevalence of adherent-invasive Escherichia coli associated with ileal mucosa in Crohn's disease. Gastroenterology. 2004; 127:412-21. [PubMed: 15300573]

76. Ozcan U, Cao Q, Yilmaz E, Lee AH, Iwakoshi NN, Ozdelen E, et al. Endoplasmic reticulum stress links obesity, insulin action, and type 2 diabetes. Science. 2004; 306:457-61. [PubMed: 15486293]

77. Sawada M, Takahashi K, Sawada S, Midorikawa O. Selective killing of Paneth cells by intravenous administration of dithizone in rats. Int J Exp Pathol. 1991; 72:407-21. [PubMed: 1883741]

78. Kamat A, Ancuta P, Blumberg RS, Gabuzda D. Serological markers for inflammatory bowel disease in AIDS patients with evidence of microbial translocation. PLoS ONE. 2010; 5:e15533. [PubMed: 21125014]

79. Wu X, Sun L, Zha W, Studer E, Gurley E, Chen L, et al. HIV protease inhibitors induce endoplasmic reticulum stress and disrupt barrier integrity in intestinal epithelial cells. Gastroenterology. 2010; 138:197-209. [PubMed: 19732776]

80. Zheng W, Rosenstiel P, Huse K, Sina C, Valentonyte R, Mah N, et al. Evaluation of AGR2 and AGR3 as candidate genes for inflammatory bowel disease. Genes Immun. 2006; 7:11-8. [PubMed: 16222343]

81. Barrett JC, Hansoul S, Nicolae DL, Cho JH, Duerr RH, Rioux JD, et al. Genome-wide association defines more than 30 distinct susceptibility loci for Crohn's disease. Nat Genet. 2008; 40:955-62. [PubMed: 18587394]

82. McGovern DP, Gardet A, Torkvist L, Goyette P, Essers J, Taylor KD, et al. Genome-wide association identifies multiple ulcerative colitis susceptibility loci. Nat Genet. 2010

83. Barrett JC, Clayton DG, Concannon P, Akolkar B, Cooper JD, Erlich HA, et al. Genome-wide association study and meta-analysis find that over 40 loci affect risk of type 1 diabetes. Nat Genet. 2009; 41:703-7. [PubMed: 19430480]

84. Moffatt MF, Gut IG, Demenais F, Strachan DP, Bouzigon E, Heath S, et al. A large-scale, consortium-based genomewide association study of asthma. N Engl J Med. 2010; 363:1211-21. [PubMed: 20860503]

85. Moffatt MF, Kabesch M, Liang L, Dixon AL, Strachan D, Heath S, et al. Genetic variants regulating ORMDL3 expression contribute to the risk of childhood asthma. Nature. 2007; 448:470-3. [PubMed: 17611496] 
86. Miller M, Tam AB, Cho JY, Doherty TA, Pham A, Khorram N, et al. ORMDL3 is an inducible lung epithelial gene regulating metalloproteases, chemokines, OAS, and ATF6. Proc Natl Acad Sci U S A. 2012; 109:16648-53. [PubMed: 23011799]

87. Cantero-Recasens G, Fandos C, Rubio-Moscardo F, Valverde MA, Vicente R. The asthmaassociated ORMDL3 gene product regulates endoplasmic reticulum-mediated calcium signaling and cellular stress. Hum Mol Genet. 2010; 19:111-21. [PubMed: 19819884]

88. Wang Y, Shen J, Arenzana N, Tirasophon W, Kaufman RJ, Prywes R. Activation of ATF6 and an ATF6 DNA binding site by the endoplasmic reticulum stress response. J Biol Chem. 2000; 275:27013-20. [PubMed: 10856300]

89. Breslow DK, Collins SR, Bodenmiller B, Aebersold R, Simons K, Shevchenko A, et al. Orm family proteins mediate sphingolipid homeostasis. Nature. 2010; 463:1048-53. [PubMed: 20182505]

90. Chatzikyriakidou A, Voulgari PV, Drosos AA. What is the role of HLA-B27 in spondyloarthropathies? Autoimmun Rev. 2011; 10:464-8. [PubMed: 21296192]

91. Ozcan U, Yilmaz E, Ozcan L, Furuhashi M, Vaillancourt E, Smith RO, et al. Chemical chaperones reduce ER stress and restore glucose homeostasis in a mouse model of type 2 diabetes. Science. 2006; 313:1137-40. [PubMed: 16931765]

92. Kars M, Yang L, Gregor MF, Mohammed BS, Pietka TA, Finck BN, et al. Tauroursodeoxycholic Acid may improve liver and muscle but not adipose tissue insulin sensitivity in obese men and women. Diabetes. 2010; 59:1899-905. [PubMed: 20522594]

93. Park SW, Ozcan U. Potential for therapeutic manipulation of the UPR in disease. Semin Immunopathol. 2013; 35 (page).

94. Berger E, Haller D. Structure-function analysis of the tertiary bile acid TUDCA for the resolution of endoplasmic reticulum stress in intestinal epithelial cells. Biochem Biophys Res Commun. 2011; 409:610-5. [PubMed: 21605547]

95. Roma MG, Toledo FD, Boaglio AC, Basiglio CL, Crocenzi FA, Sanchez Pozzi EJ. Ursodeoxycholic acid in cholestasis: linking action mechanisms to therapeutic applications. Clin Sci (Lond). 2011; 121:523-44. [PubMed: 21854363]

96. Paton AW, Beddoe T, Thorpe CM, Whisstock JC, Wilce MC, Rossjohn J, et al. AB5 subtilase cytotoxin inactivates the endoplasmic reticulum chaperone BiP. Nature. 2006; 443:548-52. [PubMed: 17024087]

97. Paton AW, Srimanote P, Talbot UM, Wang H, Paton JC. A new family of potent AB(5) cytotoxins produced by Shiga toxigenic Escherichia coli. J Exp Med. 2004; 200:35-46. [PubMed: 15226357]

98. Paton AW, Voss E, Manning PA, Paton JC. Shiga toxin-producing Escherichia coli isolates from cases of human disease show enhanced adherence to intestinal epithelial (Henle 407) cells. Infect Immun. 1997; 65:3799-805. [PubMed: 9284155]

99. Futamura Y, Tashiro E, Hironiwa N, Kohno J, Nishio M, Shindo K, et al. Trierixin, a novel Inhibitor of ER stress-induced XBP1 activation from Streptomyces sp. II. structure elucidation. J Antibiot (Tokyo). 2007; 60:582-5. [PubMed: 17917242]

100. Tashiro E, Hironiwa N, Kitagawa M, Futamura Y, Suzuki S, Nishio M, et al. Trierixin, a novel Inhibitor of ER stress-induced XBP1 activation from Streptomyces sp. 1. Taxonomy, fermentation, isolation and biological activities. J Antibiot (Tokyo). 2007; 60:547-53. [PubMed: 17917237]

101. Duboc H, Rajca S, Rainteau D, Benarous D, Maubert MA, Quervain E, et al. Connecting dysbiosis, bile-acid dysmetabolism and gut inflammation in inflammatory bowel diseases. Gut. 2012

102. Crespo I, San-Miguel B, Prause C, Marroni N, Cuevas MJ, Gonzalez-Gallego J, et al. Glutamine treatment attenuates endoplasmic reticulum stress and apoptosis in TNBS-induced colitis. PLoS ONE. 2012; 7:e50407. [PubMed: 23209735]

103. Werner T, Wagner SJ, Martinez I, Walter J, Chang JS, Clavel T, et al. Depletion of luminal iron alters the gut microbiota and prevents Crohn's disease-like ileitis. Gut. 2011; 60:325-33. [PubMed: 21076126]

104. Richardson CE, Kooistra T, Kim DH. An essential role for XBP-1 in host protection against immune activation in C. elegans. Nature. 2010; 463:1092-5. [PubMed: 20182512] 
105. Kaser A, Blumberg RS. Survive an innate immune response through XBP1. Cell Res. 2010; 20:506-7. [PubMed: 20436510]

106. Chang JS, Ocvirk S, Berger E, Kisling S, Binder U, Skerra A, et al. Endoplasmic reticulum stress response promotes cytotoxic phenotype of CD8alphabeta+ intraepithelial lymphocytes in a mouse model for Crohn's disease-like ileitis. J Immunol. 2012; 189:1510-20. [PubMed: 22753943]

107. Rivas MA, Beaudoin M, Gardet A, Stevens C, Sharma Y, Zhang CK, et al. Deep resequencing of GWAS loci identifies independent rare variants associated with inflammatory bowel disease. Nat Genet. 2011; 43:1066-73. [PubMed: 21983784]

108. Das B, Cash MN, Hand AR, Shivazad A, Grieshaber SS, Robinson B, et al. Tissue distibution of murine muc19/smgc gene products. J Histochem Cytochem. 2010; 58:141-56. [PubMed: 19826070] 


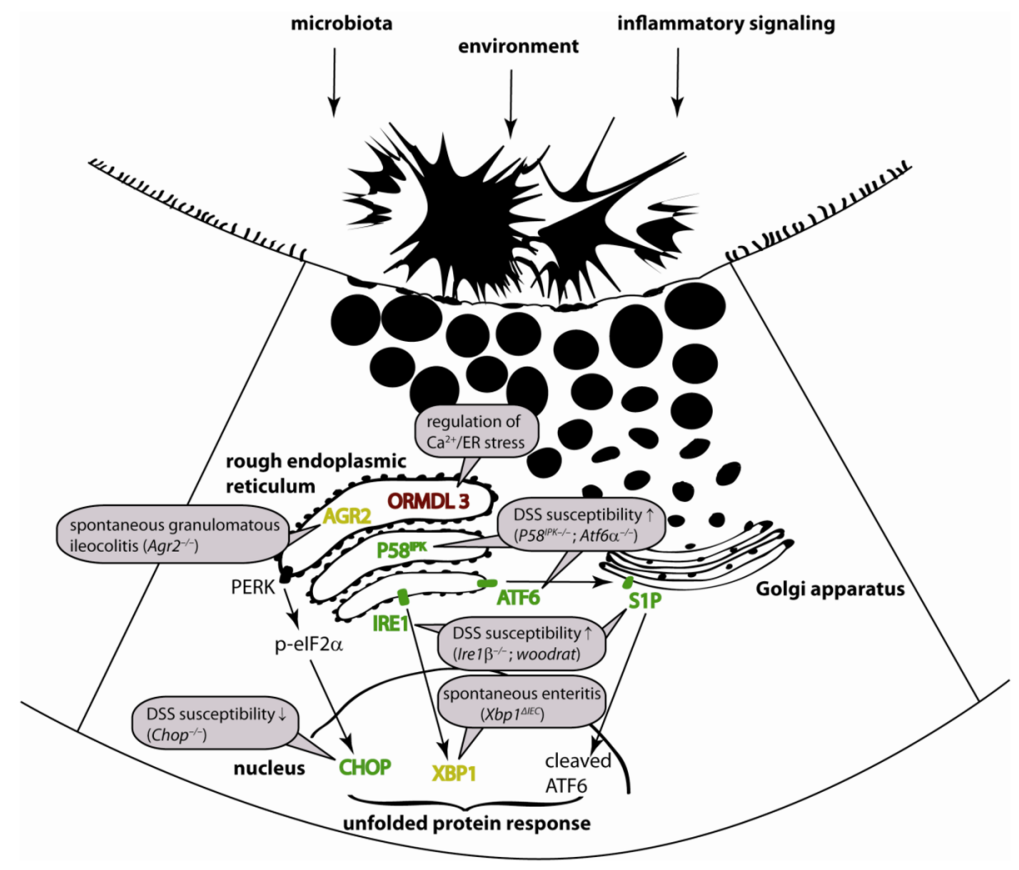

Figure 1. The unfolded protein response and IBD

ER stress arises from host factors (e.g. genetic impairment of UPR-related genes or mutations that lead to protein misfolding; inflammatory signaling) or environmental factors (e.g. diet, microbial metabolites), and consequently activates the UPR via its three main branches PERK/eIF2a/ATF4; IRE1/XBP1; ATF6/ATF6f. Genetic targeting or ENUinduced mutagenesis revealed the importance of the individual gene products for mucosal homeostasis through animal models as indicated. Several genes involved in the UPR or causing ER stress are genetic risk factors of disease as indicated. 
Table 1

ER stress-related genes, their function and disease phenotype in vivo

\begin{tabular}{|c|c|c|c|c|}
\hline ER stress related genes & Genetic association & Function & Model & Phenotype \\
\hline XBP1 (XBP1) & $\begin{array}{l}\text { CD and UC (candidate } \\
\text { gene study, deep } \\
\text { sequencing)[18] }\end{array}$ & $\begin{array}{l}\text { major UPR transcription } \\
\text { factor activated by IRE1 }\end{array}$ & $\begin{array}{l}X b p 1^{\Delta I E C}(\text { IEC- } \\
\text { specific gene } \\
\text { deletion) }\end{array}$ & $\begin{array}{l}\text { ER stress; spontaneous } \\
\text { enteritis; loss of mature Paneth } \\
\text { cells and impaired bacterial } \\
\text { handling; inflammatory hyper- } \\
\text { reactivity of the epithelium; } \\
\text { reduction in goblet cells; } \\
\text { increased sensitivity to } \\
\text { experimental colitis (DSS)[18] }\end{array}$ \\
\hline ORMDL3 (ORMDL3) & $\begin{array}{l}\text { CD, UC, asthma, T1DM } \\
\text { (genome wide association } \\
\text { studies)[81-85] }\end{array}$ & $\begin{array}{l}\text { ER resident trans- } \\
\text { membrane molecule in } \\
\text { IEC exact role not } \\
\text { entirely clear [86] }\end{array}$ & N/A & N/A \\
\hline$A G R 2$ (AGR2) & $\begin{array}{l}\text { CD and UC (candidate } \\
\text { gene study) [80] }\end{array}$ & $\begin{array}{l}\text { protein disulfide } \\
\text { isomerase (PDI), } \\
\text { disulfide bond formation } \\
\text { in proteins within the } \\
\text { ER, required for MUC2 } \\
\text { production [40] }\end{array}$ & $\begin{array}{l}\text { Agr2 } 2^{-/} \text {mouse } \\
\text { (expression in } \\
\text { secretory IEC's, [37- } \\
39]\end{array}$ & $\begin{array}{l}\text { ER stress: increased grp78 } \\
\text { expression and Xbp1 splicing; } \\
\text { spontaneous granulomatous } \\
\text { ileocolitis; alterations in Paneth } \\
\text { and goblet cells }[19,38]\end{array}$ \\
\hline ERN2 (IRE1 $\beta$ ) & Not reported & $\begin{array}{l}\text { splicing of Xbp1, } \\
\text { regulated IRE1- } \\
\text { dependent decay }\end{array}$ & $\begin{array}{l}\text { Ire } 1 \beta^{-/} \text {mouse } \\
\text { (expression } \\
\text { specifically in } \\
\text { intestinal and } \\
\text { respiratory } \\
\text { epithelium) }\end{array}$ & $\begin{array}{l}\text { ER stress: increased grp78 } \\
\text { expression; increased } \\
\text { sensitivity to experimental } \\
\text { colitis (DSS) [13]; increased } \\
\text { intestinal chylomicron secretion } \\
\text { [25] }\end{array}$ \\
\hline ATF6 ATF6a) & Not reported & $\begin{array}{l}\text { orchestrates UPR } \\
\text { downstream of ATF6 } \\
\text { when cleaved by S1P } \\
\text { and S2P }\end{array}$ & Atf $6 a^{-/}$mouse & $\begin{array}{l}\text { increased expression of ER } \\
\text { stress genes and sensitivity to } \\
\text { experimental colitis (DSS) [47] }\end{array}$ \\
\hline DNAJC3 (P58 $\left.{ }^{\mathrm{IPK}}\right)$ & Not reported & $\begin{array}{l}\text { ER resident chaperone } \\
\text { facilitating protein } \\
\text { folding }[48,49]\end{array}$ & P58IPK-/- mouse & $\begin{array}{l}\text { increased grp78 and CHOP } \\
\text { expression and IRE1 phospho- } \\
\text { rylation; increased sensitivity to } \\
\text { experimental colitis (DSS) [47] }\end{array}$ \\
\hline MBTPS1 (S1P) & Not reported & $\begin{array}{l}\text { S1P cleaves ATF6 and } \\
\text { activates other bZIP } \\
\text { transcription factors [50, } \\
51]\end{array}$ & $\begin{array}{l}\text { S1P missense } \\
\text { mutation by ENU } \\
\text { mutagenesis } \\
\text { (woodrat mouse) }\end{array}$ & $\begin{array}{l}\text { reduced grp78 and grp94 } \\
\text { expression in DSS-induced } \\
\text { colitis albeit increased } \\
\text { susceptibility [50] }\end{array}$ \\
\hline DDIT3 (СНOP) & Not reported & $\begin{array}{l}\text { downstream of PERK/ } \\
\text { ATF4, connects } \\
\text { unresolved ER stress } \\
\text { with apoptosis [14] }\end{array}$ & Chop ${ }^{-/}$mouse & $\begin{array}{l}\text { protected from DSS and TNBS } \\
\text { induced colitis [52] }\end{array}$ \\
\hline$M U C 2 *(\mathrm{MUC2})$ & $\begin{array}{l}\text { Not reported (poor } \\
\text { GWAS coverage due to } \\
\text { gene structure) }\end{array}$ & $\begin{array}{l}\text { protein of the mucin } \\
\text { family forming the } \\
\text { intestinal mucus barrier }\end{array}$ & $\begin{array}{l}\text { missense mutation in } \\
\text { Muc2 (Winnie and } \\
\text { Eeyore mouse) }\end{array}$ & $\begin{array}{l}\text { MUC2 precursor accumulation } \\
\text { accompanied by ER stress; } \\
\text { spontaneous colitis }[59,60]\end{array}$ \\
\hline $\operatorname{MUC19}{ }^{*}(\mathrm{MUC19})$ & $\begin{array}{l}\mathrm{CD} \text { and UC (genome } \\
\text { wide association studies, } \\
\text { deep sequencing) [81, } \\
107]\end{array}$ & $\begin{array}{l}\text { mucin component } \\
\text { expressed in salivary } \\
\text { glands and trachea, role } \\
\text { in other compartments } \\
\text { poorly understood [108] }\end{array}$ & N/A & N/A \\
\hline$H L A-B 27^{*}$ (HLA-B27) & $\begin{array}{l}\text { spondyloarthritis } \\
\text { (genome wide association } \\
\text { studies) [61] }\end{array}$ & $\begin{array}{l}\text { class I T-cell antigen } \\
\text { presentation }\end{array}$ & $\begin{array}{l}\text { human HLA-B27/ } \\
\beta_{2^{-} \text {microglobulin }} \\
\text { transgenic rats }\end{array}$ & $\begin{array}{l}\text { HLA-B27 prone to misfolding; } \\
\text { UPR activation in myeloid } \\
\text { cells; spondyloarthritis, ileitis, } \\
\text { arthritis, inflammatory lesions } \\
\text { of the urogenital tract, skin nail } \\
\text { and heart [62] }\end{array}$ \\
\hline
\end{tabular}

Not primarily involved in endoplasmic reticulum maintenance 